\title{
Effect of Growth Regulators and Chemicals on Germination and Growth of Rangpur Lime Seedlings under Nursery Condition
}

\author{
S. V. Yadav ${ }^{*}$, M. B. Patil ${ }^{2}$ and K. D. Mahorkar ${ }^{1}$ \\ ${ }^{1}$ Department of Horticulture, College of Agriculture, Badnapur, VNMKV, \\ Parbhani, 431402 (M.S.), India \\ ${ }^{2}$ Fruit Research Station Himayat Bagh Aurangabad, (M.S.), India \\ *Corresponding author
}

\section{A B S T R A C T}

Keywords

Rangpur lime, GA3, $\mathrm{KNO}_{3}$, NAA,

Thiourea,

Germination and growth

\section{Article Info}

Accepted:

05 February 2020

Available Online:

10 March 2020
The present investigation entitled "Effect of growth regulators and chemicals on germination and growth of rangpur lime seedlings under nursery condition"was carried out at the Instructional Cum Research Farm, sweet orange research station Badnapur, Dist- Jalna during the year 2016- 2017. The experiment was laid out in Randomized Block Design with thirteen treatments replicated thrice. The seeds will be soaked in different concentrations of $\mathrm{GA}_{3}(50,100$ and $150 \mathrm{ppm}), \mathrm{KNO}_{3}$ $(0.5 \%, 1 \%, 2 \%)$, NAA $(50,100$ and $150 \mathrm{ppm})$ Thiourea $(1 \%, 1.5 \%$ and $2 \%)$ water soaking as control for 24 hours in beaker. The results of the investigation revealed that,the seeds soaked in $\mathrm{GA}_{3} 150 \mathrm{ppm}$ solution for 12 hours prior to sowing resulted in maximum germination percentage $(91.33 \%)$. The maximum height $(52.12 \mathrm{~cm})$, maximum number of leaves $(46.59)$, maximum fresh weight $(31.35 \mathrm{~g})$ and dry weight of shoots $(16.40 \mathrm{~g})$ was also recorded under the treatment $\mathrm{T}_{3}$ i.e. $\mathrm{GA}_{3} 150 \mathrm{ppm}$ at 270 DAS. The maximum number of branches (6.66) was recorded under the treatment $\mathrm{T}_{12}$ i.e. Thiourea $2 \%$ at 270 DAS and the maximum circumference of stem $(22.23 \mathrm{~mm})$, was recorded under the treatment $\mathrm{T}_{6}$ i.e. NAA $150 \mathrm{ppm}$ at $270 \mathrm{DAS}$.

\section{Introduction}

The Rangpur lime (Citrus limonia Osbeck) is a member of the Rutaceae family. It is a citrus fruit with a very acidic taste and an orange peel and flesh. The fruit is polyembryonic and usually reproduces true to seed. A popular rootstock in many citrus growing locations, the tree evolved in Hawaii as an ornamental, when the top graft died off.

Citrus fruits have a prominent place among popular and extensively grown tropical and sub-tropical fruits. They are highly regarded for their nutritive value, wholesome nature, medicinal values and economic significance 
Citrus fruits possess greater adaptability to different climatic conditions. Internationally citrus plantation in the world is confined to 0 $40^{0}$ latitude from North to South of the equator covering different regions having different soil and climatic conditions. It shows the wide adaptability of citrus to different soil and climatic conditions.

Citrus fruits are the one of the world's most important fruit crop and are consumed mostly as fresh produce, juice, squashes, cordial and pickles. Citrus fruits have many merits. They are available throughout the year. They are not only delicious and refreshing to eat, but also provide vitamins, minerals and many other essential substances, which are required for human health. They are specially important for growing children and are an important source of vitamin ' $\mathrm{C}$ ', which plays a vital role in prevention of scurvy.

Major citrus producing states in India are Andhra Pradesh, Maharashtra, Madhya Pradesh, Punjab, Gujarat, Rajasthan, Karnataka, Assam, Odisha, Haryana and others. In India, citrus is the third most important fruit crop, after mango and banana, with an estimated production of $11655.20 \mathrm{mt}$ (in '000'MT) of fruits and area coverage of 953.40 (in '000' ha) during 2014-15. In Maharashtra production is $1454.27 \mathrm{mt}$ (in '000'MT) and area coverage of 187.41 ha ('000’ ha) (Anon, 2015).

\section{Materials and Methods}

The experiment was carried out at the Instructional Cum Research Farm, sweet orange research station Badnapur, Dist- Jalna during the year 2016- 2017. The experiment was laid out in Randomized Block Design with thirteen treatments replicated thrice. The seeds will be soaked in different concentrations of $\mathrm{GA}_{3}(50,100$ and $150 \mathrm{ppm})$, $\mathrm{KNO}_{3}(0.5 \%, 1 \%, 2 \%)$, NAA $(50,100$ and 150 ppm) Thiourea $(1 \%, 1.5 \%$ and $2 \%$ ) water soaking and control for 24 hours in beaker. The sinkers were sorted out from the floaters. The seeds will be dry for 10 minutes in shade after soaking. The dried seeds will be sown in trays, the trays will filled with soil: sand: FYM 1:1:1. Seed germination will be calculated as the proportion of germinated seedlings to the number of seeds sown and expressed in terms of percentage. Seedlings will be transferred to the polythene bags after germination.

\section{Sowing of treated seeds}

The treated seeds were sown in trays which were properly filled, labeled with tags and placed as per layout. Randomization was followed to treatment distribution in replications; every treatment included 100 seeds of Rangpur lime. The treatments were replicated thrice.

Seed treatment (soaking) and sowing was attended as per the following details.

\section{Soaking}

Date

Time

30-05-16 to 31-05-2016 9.00 pm to 9.00 am

\section{Sowing}

Date Time

31-05-2016 9.00 am to $11.00 \mathrm{am}$

\section{Results and Discussion}

\section{Seed germination percentage}

The results regarding seed germination percentage are presented in table 1 . The data revealed that, there was significant difference with respect to percentage of seed 
germination as affected by different chemical treatments under study. Maximum percentage of seed germination $(91.33 \%)$ was obtained under the treatment $\mathrm{T}_{3}\left(\mathrm{GA}_{3} 150 \mathrm{ppm}\right)$, which was significantly superior over control and rest of the treatments, while minimum seed germination percentage $(65.67 \%)$ was noticed in the treatment $\mathrm{T}_{13}$ i.e. control. The promotive effect of $\mathrm{GA}_{3}$ on seed germination might be due to its participation in the activity of alpha-amylase which catalyses the starch conversion into simple carbohydrates and chemical energy is liberated which is used in the activation of embryo (Shepley et al., 1973).

\section{Height of plant}

At the final stage of observation i.e. 270 days after sowing, the maximum plant height $(52.12 \mathrm{~cm})$ was produced by the treatment $T_{3}$ i.e. $\mathrm{GA}_{3} 150 \mathrm{ppm}$, which was significantly superior over control and rest of the treatments under study.

The next best treatment was $\mathrm{T}_{6}(51.31 \mathrm{~cm})$ i.e. NAA $150 \mathrm{ppm}$ and $\mathrm{T}_{2}$ i.e. $\mathrm{GA}_{3} 100 \mathrm{ppm}$ $(50.17 \mathrm{~cm})$. In remaining treatments also the plant height was significantly more over control. Significantly minimum plant height $(39.64 \mathrm{~cm})$ was produced under the treatment $\mathrm{T}_{13}$ i.e. control as presented in Table 1.More plant height in $\mathrm{GA}_{3}$ might have occurred due to cell division (Stowe and Yamaki, 1957) and cell elongation (Shanmugavelu, 1970), which in turn would have increased the internodal length.

\section{Number of leaves per plant}

The results regarding number of leaves per plant are presented in table 1. At 270 DAS, the maximum number of leaves per plant was produced under the treatment $\mathrm{T}_{3}$ i.e. $\mathrm{GA}_{3} 150$ ppm (46.59), which was significantly superior over control and rest of the treatments under study, except the treatment $\mathrm{T}_{2}$ i.e. $\mathrm{GA}_{3} 100$ ppm (44.37), which was at par with the treatment $\mathrm{T}_{3}$. The minimum number of leaves per plant was obtained under the treatment $T_{13}$ i.e. control (32.35), which was statistically at par with the treatment $\mathrm{T}_{10}$ i.e. Thiourea $1 \%$ (34.57). Increase in number of leaves in $\mathrm{GA}_{3}$ $150 \mathrm{ppm}$ might be due to maximum height of seedlings under this treatment. This also helps in invigoration of physiological process of plant stimulatory effect of chemicals to form new leaves at faster rate as suggested (Sharma et al., 1999 and Kadam et al., 2010).

\section{Number of branches per plant}

The results regarding number of branches per plant are presented in table 1 . More number of branches per plant (6.66) was produced in the treatment $\mathrm{T}_{12}$ i.e. Thiourea $2 \%$, which was significantly superior over control and rest of the treatments. Less number of branches per plant (3.46) was produced in the treatment $T_{13}$ i.e. control. The number of branches per plant was increased due to effect of thiourea because of its cytokinin like activity which suppresses the apical growth by stimulating lateral buds (Freez, 1978).

\section{Circumference of stem}

The treatment $\mathrm{T}_{6}$ i.e. NAA $150 \mathrm{ppm}$ recorded more circumference of stem $(22.23 \mathrm{~mm})$, which was significantly superior over all other remaining treatments, except the treatments $\mathrm{T}_{5}(21.45 \mathrm{~mm})$ and $\mathrm{T}_{3} \quad(21.44$ $\mathrm{mm}$ ), which were statistically at par with the treatment $T_{6}$. Less circumference of stem was recorded under the treatment $T_{13}$ i.e. control (12.38 mm), which was statistically at par with the treatment $\mathrm{T}_{10}$ i.e. Thiourea $1 \%$ $(13.25 \mathrm{~mm})$ as presented in Table 2.

The increase in circumference of stem with NAA and $\mathrm{GA}_{3}$ may be due to cell expansion rather than cell division (Mishra and Verma, 1980). 
Table.1 Effect of growth regulators and chemicals on Percentage of seed germination, Height of plant, number of leaves andnumber of branches per plant

\begin{tabular}{|l|c|c|c|c|c|}
\hline $\begin{array}{c}\text { Tr. } \\
\text { No. }\end{array}$ & Treatment & $\begin{array}{c}\text { Percentage of } \\
\text { seed } \\
\text { germination }\end{array}$ & $\begin{array}{c}\text { Height of plant } \\
\text { after } \\
\text { days) }\end{array}$ & $\begin{array}{c}\text { No. of leaves after } \\
\text { (270 days) }\end{array}$ & $\begin{array}{c}\text { Number of } \\
\text { branches } \\
\text { per plant }\end{array}$ \\
\hline $\mathbf{T}_{\mathbf{1}}$ & GA3 50 ppm & 88.08 & 50.15 & 39.40 & 4.80 \\
\hline $\mathbf{T}_{\mathbf{2}}$ & GA3 100 ppm & 88.66 & 50.17 & 44.37 & 5.10 \\
\hline $\mathbf{T}_{\mathbf{3}}$ & GA3 150 ppm & 91.33 & 52.12 & 46.59 & 5.30 \\
\hline $\mathbf{T}_{\mathbf{4}}$ & NAA 50 ppm & 79.00 & 43.12 & 36.63 & 5.40 \\
\hline $\mathbf{T}_{\mathbf{5}}$ & NAA 100 ppm & 88.10 & 50.02 & 39.33 & 5.60 \\
\hline $\mathbf{T}_{\mathbf{6}}$ & NAA 150 ppm & 82.67 & 51.31 & 44.39 & 5.66 \\
\hline $\mathbf{T}_{\mathbf{7}}$ & KNO3 @ 0.5 \% & 84.33 & 42.46 & 36.10 & 4.46 \\
\hline $\mathbf{T}_{\mathbf{8}}$ & KNO3 @ 1 \% & 88.11 & 42.10 & 36.48 & 4.66 \\
\hline $\mathbf{T}_{\mathbf{9}}$ & KNO3 @ 1.5 \% & 79.67 & 50.08 & 39.41 & 5.46 \\
\hline $\mathbf{T}_{\mathbf{1 0}}$ & Thiourea @ 1\% & 78.67 & 40.60 & 34.57 & 6.00 \\
\hline $\mathbf{T}_{\mathbf{1 1}}$ & Thiourea @ 1.5\% & 76.33 & 40.88 & 34.70 & 6.26 \\
\hline $\mathbf{T}_{\mathbf{1 2}}$ & Thiourea @ 2 \% & 77.33 & 41.54 & 35.65 & 6.66 \\
\hline $\mathbf{T}_{\mathbf{1 3}}$ & Control & 65.67 & 39.64 & 32.35 & 3.46 \\
\hline & SEm \pm & 1.19 & 1.08 & 0.80 & 0.30 \\
\hline & CD@5\% & 3.46 & 3.15 & 2.34 & 0.89 \\
\hline
\end{tabular}

Table.2 Effect of growth regulators and chemicals on Circumference of stem, fresh weight of shoot and Dry weight of shoot

\begin{tabular}{|l|c|c|c|c|}
\hline Tr. No. & Treatment & $\begin{array}{c}\text { Circumference } \\
\text { of stem }(\mathbf{c m})\end{array}$ & $\begin{array}{c}\text { fresh weight of } \\
\text { shoot }(\mathbf{g m})\end{array}$ & $\begin{array}{c}\text { Dry weight of } \\
\text { shoot (gm) }\end{array}$ \\
\hline $\mathbf{T}_{\mathbf{1}}$ & GA3 50 ppm & 17.40 & 25.76 & 14.42 \\
\hline $\mathbf{T}_{\mathbf{2}}$ & GA3 100 ppm & 18.47 & 27.97 & 15.61 \\
\hline $\mathbf{T}_{\mathbf{3}}$ & GA3 150 ppm & 21.44 & 31.35 & 16.40 \\
\hline $\mathbf{T}_{\mathbf{4}}$ & NAA 50 ppm & 19.84 & 22.15 & 13.15 \\
\hline $\mathbf{T}_{\mathbf{5}}$ & NAA 100 ppm & 21.45 & 23.47 & 13.17 \\
\hline $\mathbf{T}_{\mathbf{6}}$ & NAA 150 ppm & 22.23 & 28.41 & 15.71 \\
\hline $\mathbf{T}_{\mathbf{7}}$ & KNO3 @ 0.5 \% & 18.45 & 20.68 & 9.23 \\
\hline $\mathbf{T}_{\mathbf{8}}$ & KNO3 @ 1 \% & 18.59 & 20.90 & 10.25 \\
\hline $\mathbf{T}_{\mathbf{9}}$ & KNO3 @ 1.5\% & 16.96 & 24.19 & 10.68 \\
\hline $\mathbf{T}_{\mathbf{1 0}}$ & Thiourea @ 1\% & 13.25 & 18.19 & 8.69 \\
\hline $\mathbf{T}_{\mathbf{1 1}}$ & Thiourea @ 1.5\% & 14.42 & 18.90 & 8.88 \\
\hline $\mathbf{T}_{\mathbf{1 2}}$ & Thiourea @ 2 \% & 16.40 & 19.40 & 9.12 \\
\hline $\mathbf{T}_{\mathbf{1 3}}$ & Control & 12.38 & 15.44 & 6.81 \\
\hline & SEm \pm & 0.048 & 1.23 & 0.48 \\
\hline & CD $@ \mathbf{5 \%}$ & 0.93 & 3.60 & 1.41 \\
\hline
\end{tabular}




\section{Fresh weight of shoots}

The results regarding fresh weight of shoots are presented in table 2. In Rangpur lime significantly more fresh weight was produced by the treatment $\mathrm{T}_{3}$ i.e. $\mathrm{GA}_{3} 150 \mathrm{ppm}(31.35$ $\mathrm{g}$ ), followed by the treatments $\mathrm{T}_{6}(28.41 \mathrm{~g})$ and $\mathrm{T}_{2}(27.97 \mathrm{~g})$ over control and rest of the treatments. Significantly less fresh weight of shoots was observed under the treatment control $(15.44 \mathrm{~g})$. This seems to be the effect of mobilization of water and nutrients transported at higher rate which might have promoted more production of photosynthetic product and translocated them to various plant parts which have resulted in better growth of seedlings and hence more fresh weight (Brain et al., 1954 and Shanmugavelu, 1966).

\section{Dry weight of shoots}

The results regarding dry weight of shoots are presented in table 2 . Significantly more dry weight of shoots was recorded in the treatment $\mathrm{T}_{3}$ i.e. $\mathrm{GA}_{3} 150 \mathrm{ppm}(16.40 \mathrm{~g})$, followed by the treatments $\mathrm{T}_{6}(15.71 \mathrm{~g})$ and $\mathrm{T}_{2}$ (15.61 g), over control and rest of the treatments. Significantly minimum dry weight of shoots was obtained under the treatment control $(6.81 \mathrm{~g})$. This seems to be the effect of mobilization of water and nutrients transported at higher rate which might have promoted more production of photosynthetic product and translocated them to various plant parts which have resulted in better growth of seedlings and hence more fresh weight and dry weight (Brain et al., 1954 and Shanmugavelu, 1966).

On the basis of present investigation the following conclusion can be drawn. Effect of growth regulators and chemicals has got significant effect on seed germination, vegetative growth of rangpur lime. The maximum percentage of seed germination and the growth attributes like height of plant, number of leaves per plant, fresh and dry weight of shoots was maximum with the seed treatment of $\mathrm{GA}_{3}$ at $150 \mathrm{ppm}$. The remaining growth attributes like circumference of stem was maximum with the seed treatment of NAAat 150 ppm.

\section{References}

Anonymous, 2015. Horticulture Statistics at a glance, Govt. of India, MoA, Department of Agriculture and Cooperation, New Delhi.

Brain, P.W. (1954). Effect of gibberellins on plant growth and development. Biol. Rev. 34: 37-84.

Freez, A. 1978. Thiourea a growth promoter of callus tissues J.Exp. Bot. 29 (108): 159-165.

Kadam, A.B., Singh, D.B. and Kade, R.A. (2011). Effect of plant growth regulators and potassium nitrate on growth of seedling of Rangpur lime. International Journal of Agricultural Sciences, 7 (1): 96-99.

Shanmugavelu, K.G. (1966). Studies on the effect of plant growth regulator on the seedling of some tree plant species. South Indian Hort.14:24-25.

Shanmugavelu, K.G. (1970). Effect of gibberellic acid on seed germination and development of seedling of some tree species. Madras Agric. J. 57(6):311-314.

Sharma, M.C., Ughreia, P.P.U. and Jambukia, T.K. (1999). Effect of some plant growth regulators, chemicals and organic waste on germination and subsequent seedling growth of kagzi lime

Stowe, B.B. and Yamaki, T. (1957). The history and physiological action of the gibberellins. Ann. Rev. Plant Physio. 8: 181-216. 
How to cite this article:

Yadav, S. V., M. B. Patil and Mahorkar, K. D. 2020. Effect of Growth Regulators and Chemicals on Germination and Growth of Rangpur Lime Seedlings under Nursery Condition. Int.J.Curr.Microbiol.App.Sci. 9(03): 836-841. doi: https://doi.org/10.20546/ijcmas.2020.903.098 